\title{
P-101
}

\section{Congestiflorone, a Potential Inhibitor Against Human b Lymphoma}

\author{
Soek Sin Teh ${ }^{1, *}$, Gwendoline Cheng Lian $\mathrm{Ee}^{1}$, Siau Hui Mah ${ }^{1}$, Yang Mooi Lim² ${ }^{2}$ and Mawardi \\ Rahmani $^{1}$ \\ ${ }^{I}$ Department of Chemistry, Faculty of Science, Universiti Putra Malaysia, 43400 UPM Serdang, Selangor, Malaysia; \\ ${ }^{2}$ Faculty of Medicine and Health Science, Universiti Tunku Abdul Rahman, 43000, Kajang, Selangor, Malaysia; \\ E-mail: judith_teh@hotmail.com
}

The interest in the development and discovery of natural products as alternative drugs rather than synthetic conventional drugs in the pharmaceutical industry is increasing dramatically recently. An investigation on the secondary metabolites from the roots of Mesua congestiflora (Clusiaceae) was carried out. A new benzophenone - congestiflorone (1) and one xanthone, $\alpha$ mangostin (2) were obtained. The structure and relative configuration of the new compound was determined using NMR spectroscopy and X-ray crystallographic techniques. The cytotoxic activities of the metabolites and crude extracts against a panel of cancer cell lines which are Raji (lymphoma), SNU-1 (stomach), LS-174T (colon), HeLa (cervical), SK-MEL-28 (skin), NCI-H23 (lung), IMR-32 (neuroblastoma), Hep-G2 (liver) and K562 (leukemia) were evaluated using the MTT assays. Congestiflorone (1) showed dose-dependent inhibition of proliferation against lymphoma cell line (Raji). Additionally, only the hexane extract of Mesua congestiflora reflected mild cytotoxicities towards SNU-1, K562 and NCI-H23 cells.

Keywords: Clusiaceae; Mesua congestiflora, Benzophenone, Congestiflorone, Cytotoxic. 